\title{
Articles
}

\section{Electrochemical Assay of Neurotransmitter Glycine in Brain Cells}

\author{
Suw Young Ly* and Dong Young Kim \\ Biosensor Research Institute, Seoul National Lnwersity of Technologn, Seoul 139-743, Korea. E-mail: suwvoungat snutac.kr \\ -Adwanced Scientific Experiment Group in DaeJin High School, Seoul 139-230, Korea \\ Recerved November 20,2006
}

\begin{abstract}
Neurotransmitter glycine in the nano gram range was analyzed using a paste electrode (PE) in cyclic voltammetry (CV) and square-wave stripping voltammetry (SWSV). An anodic peak caused by oxidation of the glycine ion appeared at the $0.4 \mathrm{~V}$ (versus $\mathrm{Ag} / \mathrm{AgCl} / \mathrm{KCl}$ ) potential in a $0.1 \mathrm{M} \mathrm{NH}_{4} \mathrm{H}_{2} \mathrm{PO}_{4}$ electrolyte solution. At optimized conditions. the working range of the SWSV and CV concentration was found to be 5$60 \mathrm{ngL}^{-1}$ glycine: precision of $\mathrm{R}^{2}=0.9816$ (SWSV) and $0.9986(\mathrm{CV})$; and detection limit of $0.65 \mathrm{ngL}^{-1}$ $\left(5.82 \times 10^{-12} \mathrm{molL}^{-1}\right)(\mathrm{S} / \mathrm{N}=3)$. The optimized conditions were applied to an assay in a fish brain tissue and a living brain cell in real time.
\end{abstract}

Key Words : Voltammetry. Neurotransmitter, Glycine. Fish. Brain

\section{Introduction}

Neurotransmitters of glycine and their corresponding analogy are present in the composition of the brain. liver. lung and kidney tissue in the human body. Diagnosis of this extracellular brain assay is important in the evaluation of schizophrenia. anxiety related disorders. stroke. Parkinson 's disease. and depression. ${ }^{l}$ Measuring neurotransmitters is important in medicine. neuropsychiatric science and other analytical fields. ${ }^{3}$ It has been shown that various analytical methods achieve low detection limit (DL) in laboratory conditions. For example. liquid chromatography achieved $5.07 \mathrm{nM}$ DL per $20 \mu \mathrm{L}$ injection volume. ${ }^{2}$ a solid-state optically based selective sensor yielded DL: $30 \mathrm{nM}^{4}{ }^{4}$ an $\mathrm{H}^{1}-$ NMR spectra method yielded DL: $15 \mu \mathrm{M}$. an HPLC-fluorescence detector yielded DL: $40 \mathrm{nM}^{6}$ a high-performance liquid chromatography with photodiode array detection yielded DL: $0.154 \mu \mathrm{M}^{7}$ a high-performance liquid chromatographic and colorimetric assay exhibited DL: $6 \mathrm{ng} .{ }^{8}$ capillary electrophoresis with laser-induced fluorescence detection exhibited DL: $23 \mathrm{nM}$. capillary electrophoresis with lightemitting diode-induced fluorescence detection yielded DL: $9.3 \mathrm{nM}^{10}$ and a column-switching HPLC tandem mass spectrometric method yielded a concentration range of 5-200 ngmL ${ }^{-1}{ }^{11}$ However all these methods demand separation and other detection systems. such as photometric or electrochemical systems. In analytical science. simpler and more sensitive methods are required. Electrochemical systems have long been recognized as simple. fast and powerful tools for trace analysis. ${ }^{12-14}$ In biological assay glycine and its analogy are composed of very low concentration ranges of nano- or picogram ranges. In this study. a highly sensitive working electrode was prepared using a new type of carbon nanotube electrode exhibiting various phỵsical and electro- chemical properties. ${ }^{15-20}$ Moreover. DNA, which has a specific affinity for various molecular recognition in analytical chemistry:" was immobilized on the carbon nanotube surface using cyclic voltanmetry. DNA's electrical biosensing property was seen in several other papers. ${ }^{22-25}$ and can be used in a bioassay ${ }^{26.27}$ that described the optimization of a combined electrode for glycine assay. This successfully yielded a lower detection limit compared to common analytical methods. ${ }^{2 .-110}$ The results were applied in real-time assay in mammalian tissue and can also be applicable to human neuropsychiatric science in real time.

\section{Experimental Design}

Preparation of Electrode. The PE working sensor was made with a DNA carbon nanotube and mineral oil. The PE was prepared by mixing $40 \%$ nanotube graplite powder (Nanostructured \& Amorphous Materials. Inc.) and 40\% DNA (double-stranded and prepared from calf thymus sigma) with $20 \%$ mineral oil. The mixture was homogenized in a mortar for 30 minutes. The mixed paste was then inserted into a $5 \mathrm{~cm}$-long plastic needle-ty'pe capillary tube with a diameter of $1.5 \mathrm{~mm}$. and a copper wire with a diameter of $0.5 \mathrm{~mm}$ was connected to the electrochemical measurement system. An $\mathrm{Ag} / \mathrm{AgCl}$ electrode and a platinum wire electrode served as the reference electrode and the auxiliary electrode. respectively. A three-electrode cell was used to monitor the voltammetric signal.

Reagents. All experimental solutions were prepared from $18 \mathrm{M} \mathrm{ohm} \mathrm{cm}^{-1}$ double-distilled water. A $0.1 \mathrm{M} \mathrm{NH}_{4} \mathrm{H}_{2} \mathrm{PO}_{4}$ solution with a $\mathrm{pH}$ level of 4.75 served as a supporting electrolyte solution. Standard glycine was prepared with an analytical grade of Aldrich Chemical Co (111.5: MW glycine- $\mathrm{HCl}$ ). All the systems were carried out in dissolved 
oxygen. and an electrode cleaning time was not necessary for every measurement. The phosphoric acid solution was found to be the most suitable medium.

Experimental Procedure. The common parameter for $\mathrm{CV}$ was a scan rate of $100 \mathrm{mVs}^{-1}$, and the common parameters for SWSV were set at optimized conditions. DNA immobilization was performed through a cyclic scan with an initial potential of $+1.6 \mathrm{~V}$. a switching potential of $0.6 \mathrm{~V}$. and a scan rate of $0.5 \mathrm{mVs}^{-1}$, with a tan cyclic repeat to stabilize the electrode surface. Since the voltammetric response of glycine is dependent on the electrolyte solutions and the hyddrogen ionic strength. various types of electrolyte solutions were tested. The phosphate solution was found to yield the best results.

\section{Results and Discussion}

Cyclic Voltammetry. First. peak potentials for glycine were detemined using wide potential ranges from -0.8 to $1.6 \mathrm{~V}$. At the anodic scan. strong current of $0.4 \mathrm{~V}$ and weak current of $0.8 \mathrm{~V}$ potentials were obtained under which $0.4 \mathrm{~V}$ oxidation occurred on the electrode surface with glycine adsorbates for the cationic (1): $\mathrm{NH}_{3}{ }^{-} \mathrm{CH}_{2} \mathrm{COOH}<-\mathrm{C}_{3}$ (l)acld range $\left.\cdots>\mathrm{NH}_{3}{ }^{-} \mathrm{CH}_{2} \mathrm{COO}^{-}<\cdots\right)_{2}-\mathrm{NH}_{2} \mathrm{CH}_{2} \mathrm{COO}^{-}$. while other $0.8 \mathrm{~V}$ peak potentials depended on the second reaction (2). In this configuration. glycine varies from being cationic. zwitterionc. and anionic by the accumulation potential and hy'drogen ionic strength. ${ }^{25}$-31) and only irreversible anodic current appeared. ${ }^{31}$ Thus analytically usable $0.4 \mathrm{~V}$ peak potentials were examined using increased concentrations. Figure 1(A) shows the results. where conditions of $0.4 \mathrm{~V}$ also linearly moreased. All the other experments used these results. In Figure l(B). more exact peak potentials were compared using the common type glassy carbon. the pencil type electrode ${ }^{33 \cdot 33}$ the carbon nanotube paste electrode. and the DNA-mixed carbon nanotube paste electrode. and obtained the same peak potentials. Calibration curve shows 4 points of $0.2-0.8 \mathrm{mgL}^{-1}$ glycine spikes in the same

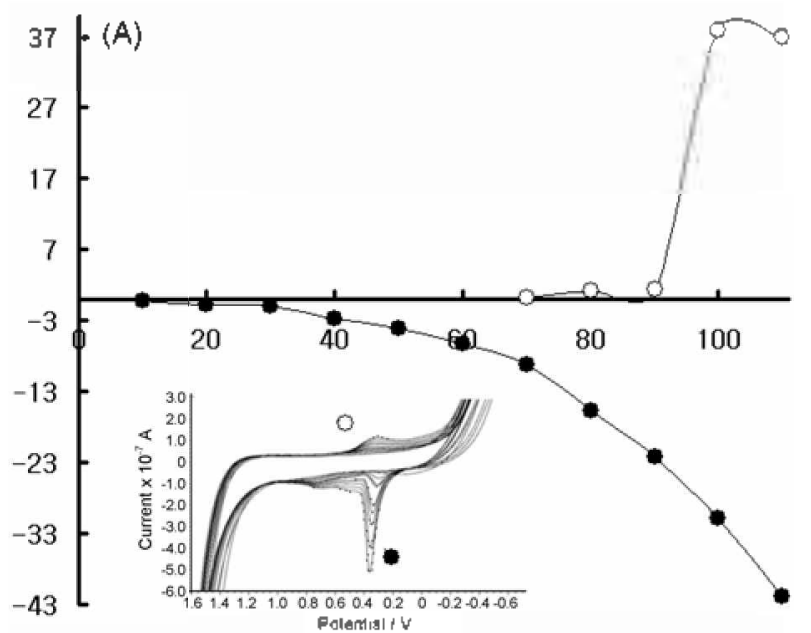

contamed cell. Both peaks appeared at the same potential of $0.4 \mathrm{~V}$ and peak highs of $7.23 \times 10^{-5} \mathrm{~A}$ (DNAPE) and 0.934 $\times 10^{-5} \mathrm{~A}$ (nanotube) were obtained. In the figure, the DNAPE electrode is shown to have more sensitively responded compared to the nanotube electrode. Thus. more sensitive working ranges were examined using SWSV accumulation șistems.

Optimization of SW Parameters. The SWSV accumulation time was determined to be in the range of $50-500 \mathrm{~s}$ with 10 points using magnetic stirring condition. Figure 2(A) shows the results. At the range of $50-300 \mathrm{~s}$. the peak current very quickly responded and the peak width sharply appeared under which $-0.43 \mathrm{~V}$ depended on the diffusion and migration effects of (2) $\mathrm{NH}_{3}{ }^{-} \mathrm{CH}_{2} \mathrm{COO}^{-}<-$(2) $^{--\rangle^{\prime}>}$ $\mathrm{NH}_{2} \mathrm{CH}_{2} \mathrm{COO}^{-}$. whereas from 300 to $500 \mathrm{~s}$, the peak high slowly decreased and reached a steady state. The maximum peak was found to be at the $300 \mathrm{~s}$ accumulation time with $10.58 \pm 0.75 \times 10^{-6} \mathrm{~A}$ mean peak was repeatedly measured $(n=3 . \mathrm{RSD}=9.58 \%)$. All the other experiments were performed using these results. At these conditions. the accumulation potential was examined using an anodic scan from -0.5 to $0.2 \mathrm{~V}$. Figure $2(\mathrm{~B})$ shows the results. The peak width did not change and only the peak high responded. and $-0.4 \mathrm{~V}$ peak potential sensitively appeared with a $10.44 \pm$ $0.65 \times 10^{-7}$ A mean $(n=4$. RSD $=8.50 \%)$, peak current high. This slowly and continuously decreased afterwards. The results indicate poorer response compared to the accumulation time. and an examination of the negative stripping showed that no signals were obtained. Electrolyte hyddrogen ionic strength was determined ușing $0.1 \mathrm{M} \mathrm{NaOH}$ and $0.1 \mathrm{M} \mathrm{HCl}$ solution spiking. Figure 2(C) shows the effects. In the acid and more base ranges of $\mathrm{pH} 2.58-4.06$ and 5.37-7.76. the peaks did not respond and at the $4.75 \mathrm{pH}$. large currents of $4.437 \pm 0.55 \times 10^{-6} \mathrm{~A}$ mean $(n=3, \mathrm{RSD}=$ $7.60 \%$ ) appeared. as influence of the hydrogen reaction of

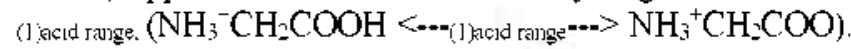
The results appear to be more sensitive compared to the accumulation potential but less sensitive than the accumu-

(B)

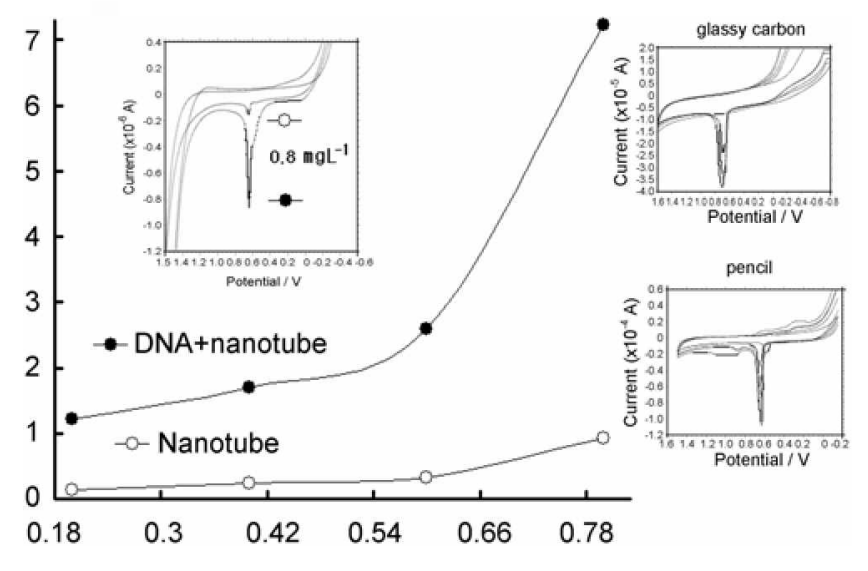

Figure 1. (A): Cyclic voltammetry for DNAPE, various concentrations of $10-, 20-, 30-, 40-, 50-, 60-, 70-, 80-, 90-, 100-$ and $110 \mathrm{ngL}-1$ glycine spike (B): Comparison of the carbon nanotube (- - - ) and DNAPE (- - ) electrodes in glycine concentrations of $0.2,0.4,0.6$ and 0.8 $\mathrm{mgL}^{-1}$ using cyclic voltammetry (imer CV: $0.8 \mathrm{mgL}^{-1}$ ) in a $0.1 \mathrm{M}$ ammonium phosphate solution ( $\mathrm{pH} 4.5$ ) with a scan rate of $100 \mathrm{mVs}^{-1}$. 

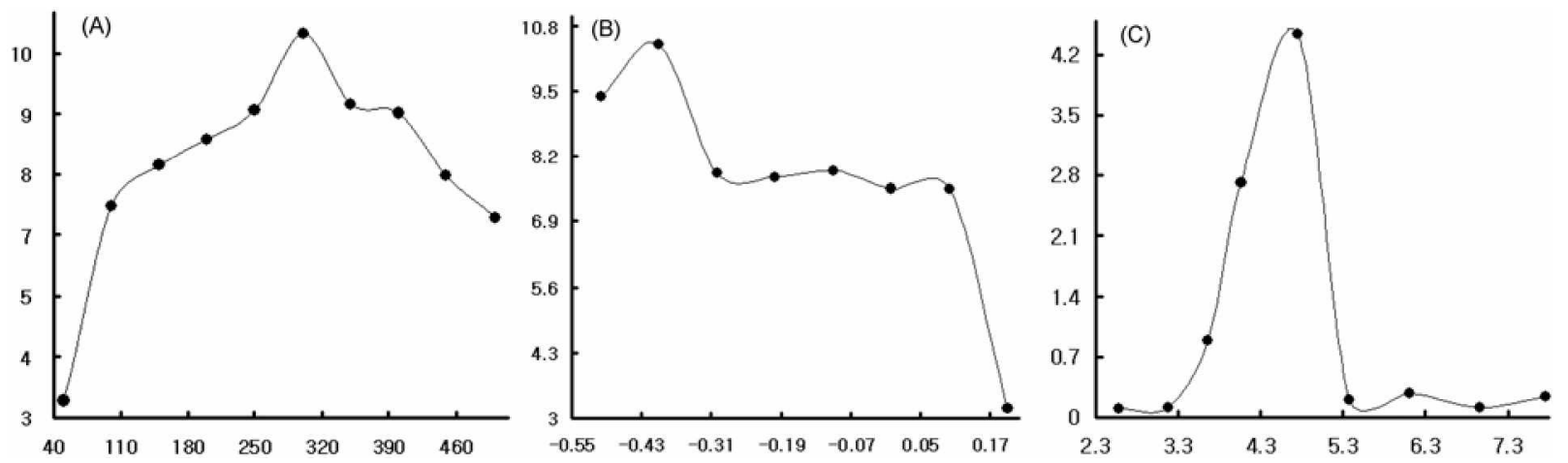

Figure 2. (A): Cument response in SWSV accunulation times of $50,100,150,200,250,300,350,400,450$ and 500 s. (B): Accumulation potentials of $-0.5,-0.4,-0.3,-0.2,0,0.1$ and $0.2 \mathrm{~V}$. (C): Electroly te hydrogen ionic strength for $2.58,3.18,3.66,4.75,5.37,6.11,6.96$ and $7.76 \mathrm{pH}$ in $0.65 \mathrm{mgL}^{-1}$ glycine spike. Other experimental conditions used are the same as those in $\mathrm{Fig} .3$.
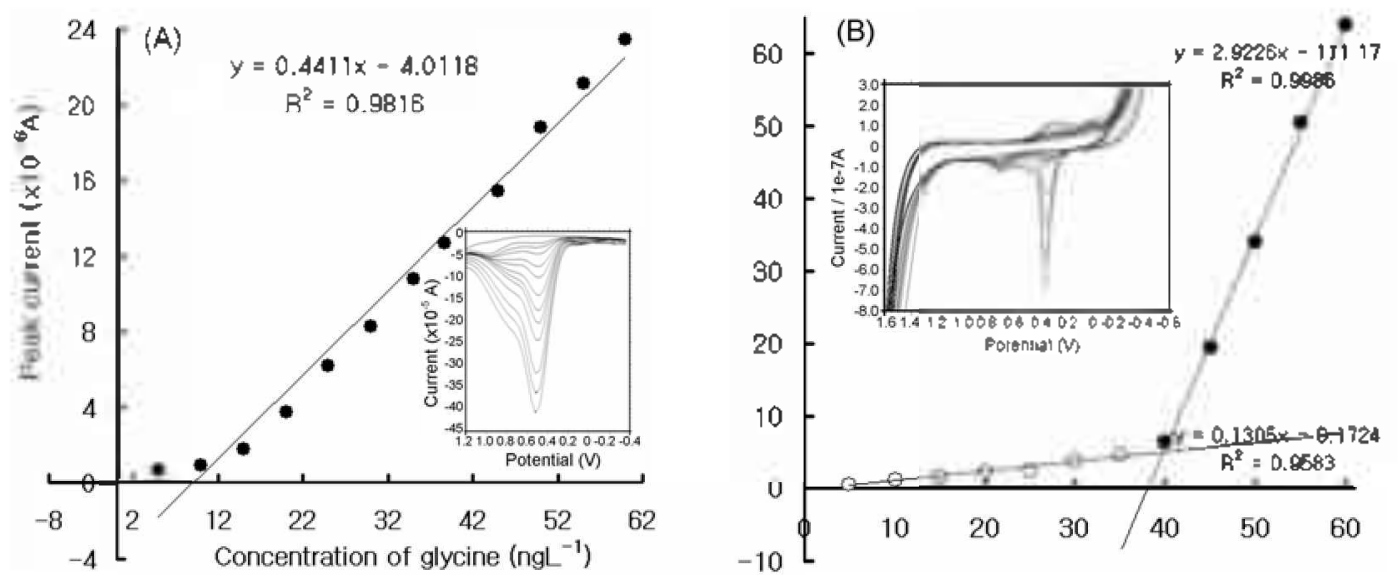

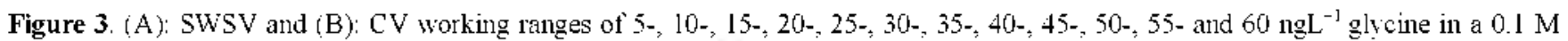
ammonium phosphate solution. SWSV: An amplitude of $0.2 \mathrm{~V}$, trequency of $500 \mathrm{~Hz}$, accumulation potential of $-0.4 \mathrm{~V}$ and accumulation time of $300 \mathrm{~s}$ were used with a $\mathrm{pH}$ of 4.75 . CV: An initial potential of $-0.6 \mathrm{~V}$, switching potential of $1.6 \mathrm{~V}$ and scan rate of $0.5 \mathrm{~V} / \mathrm{s}$ were used.

lation times shown in Figure 2(A). At optinized conditions. other parameters of the SW frequency the SW increment potential. and the SW amplitude were examined. and the results of $500 \mathrm{~Hz}, 0.04 \mathrm{~V}$ and $0.20 \mathrm{~V}$ as obtained are not shown here. At these conditions. various analytical interference ions were examined by adding other metals and analog neurotransmitters into the medium containing 0.1 $\mathrm{mgL}^{-1}$ of glycine, for the tenfold spiking of $1 \mathrm{mgL}^{-1}$ of $\mathrm{Co}$. $\mathrm{Ba} . \mathrm{Bi} . \mathrm{Ge} . \mathrm{Ca}$. Fe $\mathrm{Cr}$. dopamine catechol epinephrine. vitamin $\mathrm{C}$. and glucose ions. This yielded results of $62.5 \%$. $760.7 \%$. $137.9 \%, 182.9 \%$. 194.2\% $293.2 \%,-40.1 \% .19 .8$ $\% .14 .8 \%, 32.2 \%, 38.2 \%$ and $48.9 \%$. respectively. The analytical interferences were effectively corrected using standard addition methods. At these conditions. the usable working range was examined using SWSV and CV.

Statistics, Working Range and Application in Brain Tissue. At optimized conditions. detectable working ranges of milli- and microgram ranges were obtained. whereas Figure 3(A) shows the nanogram ranges for SWSV and CV in raw voltammograms. All the peaks sharply responded from $15-$ to $60 \mathrm{ngL}^{-1}$ SWSV with 10 points. and the linear equations for the $\Delta \mathrm{x} / \Delta \mathrm{y}=0.4411$ sensitivity, the -4.0118 intersection. and the $\mathrm{R}^{2}=0.9816$ precision were calculated. This is shown to be more highly sensitive conpared to other common methods. Figure $3(\mathrm{~B})$ shows that the $\mathrm{CV}$ results at the 5-35 nanogram range increased slowly and the peak currents responded to the slope ratio of $\Delta \mathrm{x} / \Delta \mathrm{y}=0.1305$ 0.1724 and the precision of $\mathrm{R}^{2}=0.9583$. The range of $40-60$ $\mathrm{ngL}^{-1}$ glycine for the five points linearly increased with $\Delta \mathrm{V} /$ $\Delta y=2.9226$ and the intersect of -111.17 , the precision of $R^{2}$ $=0.9986$ was calculated. the $0.4 \mathrm{~V}$ potential appeared, and small $0.8 \mathrm{~V}$ anodic and $0.4 \mathrm{~V}$ cathodic peaks were obtained. These two peaks were not used in the analytical applications. These results show that the SW peak current responded more sensitively compared to the CV peak high.

Finally, an analytical application was carried out on living fish. Figure $4(\mathrm{~A})$ shows the diluted fish brain tissue. A fish sample was prepared with an extracted $0.2781 \mathrm{~g}$ brain tissue with flashly and diluted in $10 \mathrm{~mL}$ distilled water with one drop each of $0.1 \mathrm{M} \mathrm{HNO}_{3}$ and etlyyl alcohol added. Figure 4(A) shows that the first blank curve did not obtain any signal. Subsequently, the $0.2 \mathrm{~mL}$ tissue solution was spiked. and at this curve. a small peak potential of $0.4 \mathrm{~V}$ appeared at the same conditions as those of the other cells. Moreover. $20-$ and $40 \mu \mathrm{gL}^{-1}$ glycine were spiked, and the $1.24 \pm 0.45$ $\mu \mathrm{g} / \mathrm{mL}$ mean $(n=3$. RSD $=5.40 \%)$ result was calculated using the standard addition method. This can be applied to in vivo diagnosis. Figure $4(B)$ shows the electric circuit of an 


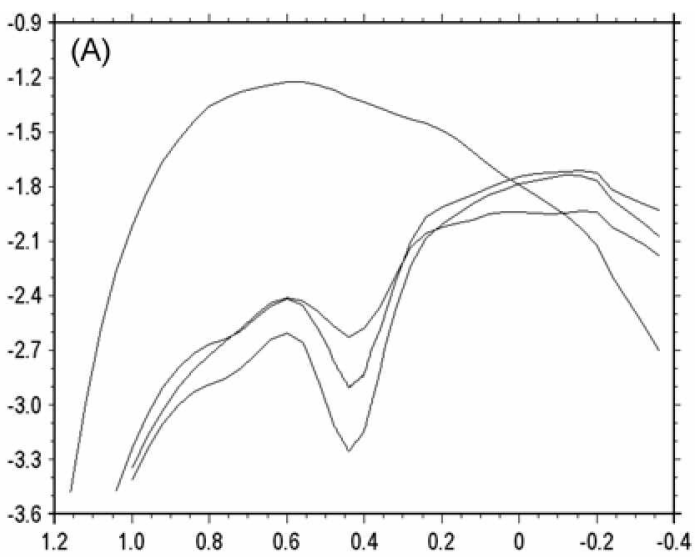

(B)
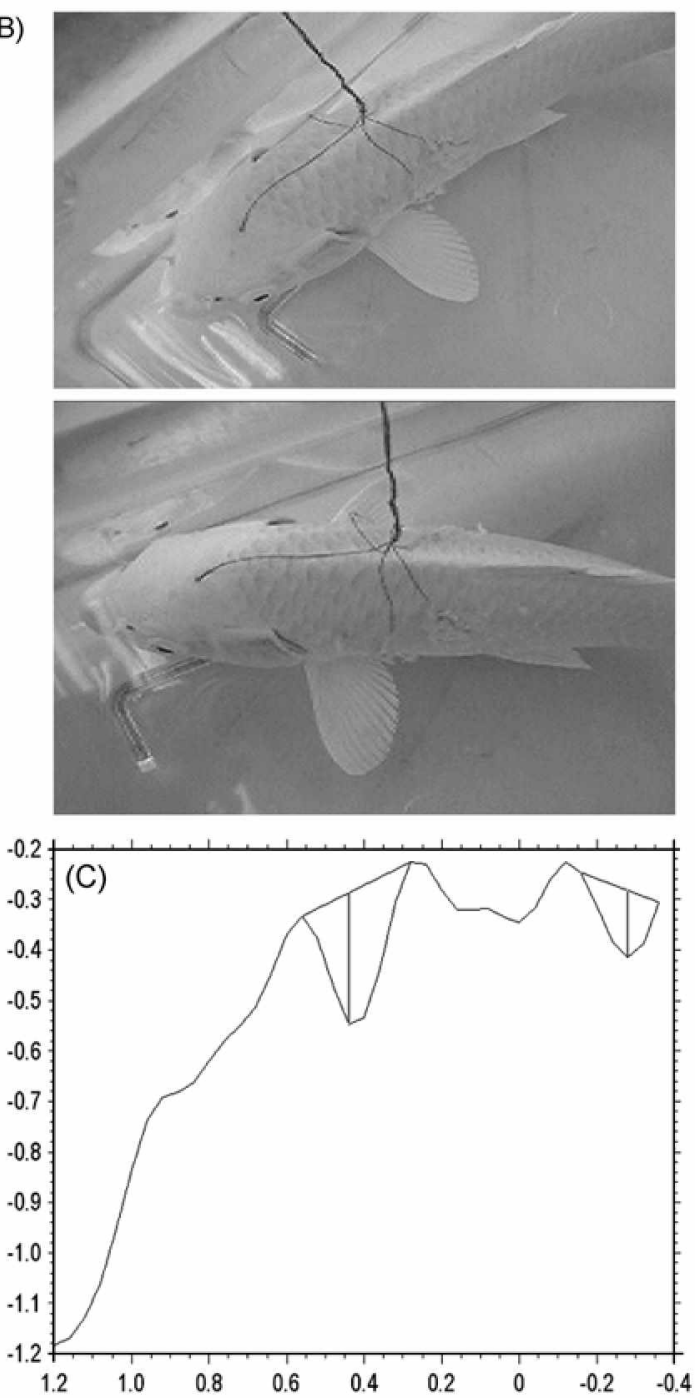

Figure 4. (A): Application of diluted brain tissue with SWSV. The first peak corresponds with the blank solution, while the next peak corresponds with the diluted tissue solution of $0.2 \mathrm{~mL}$ spike and the 20- and $40 \mathrm{~kg} / \mathrm{L}$ glycine standard solution spikes. The other parameters in Fig. 3 were also used here. (B): $h$ wivo assay at a living brain core. (C) The peak current of (B).

in vivo implantation, indicating better sensitivity in the application on living fish brain tissue. A working electrode was inserted in the fish brain's $7 \mathrm{~mm}$ core using a needle- type micro hand drill with a $0.2 \mathrm{~mm}$ diameter under anesthesia. A $10 \mathrm{~mm}$ long $\mathrm{Ag} / \mathrm{AgCl}$ : $\mathrm{Cl}$ coated $\mathrm{Ag}$ wire with a $0.1 \mathrm{~mm}$ diameter was used as the reference electrode. A counter electrode (Pt $0.1 \mathrm{~mm}$ diameter) was inserted $5 \mathrm{~mm}$ deep into the backbone tissue, and all the electrodes were cemented with a tooth binder and connected to a $0.05 \mathrm{~mm}$ enamel-coated copper wire with an electrochemical system. Stripping was performed at optimized conditions. Figure 4 (C) shows the results of $0.26 \times 10^{-6} \mathrm{~A}$ peak high. at $0.4 \mathrm{~V}$. an anodic peak current was successfully obtained. which can be used in any other mammalian assay in real time. Expanded applications were performed with known contents of 20.0 $\mathrm{mg} / \mathrm{L}$ glycine for D-company's product in Korea with a drug sample of one tablet. The results yielded contents of $19.7 \pm$ $0.56 \mathrm{mgL}^{-1} \mathrm{~A}$ mean $(n=3 . \mathrm{RSD}=6.70 \%)$ at optimal conditions. The values had satisfactory results that ranged from $95 \%$ to $105.5 \%$. The proposed methods can be useful in extracellular. neuropsychiatric and other medicinal assays.

\section{Conclusions}

Voltammetric analysis of glycine was perfonmed using DNA immobilized on a carbon nanotube PE. The optinum analytical conditions were set at $300 \mathrm{~s}$ accumulation time. $-0.4 \mathrm{~V}$ initial potential. $4.75 \mathrm{pH}$ strength. $500 \mathrm{~Hz} \mathrm{SW}$ frequency. $0.04 \mathrm{~V} \mathrm{SW}$ increment and $0.20 \mathrm{~V} \mathrm{SW}$ amplitude. The results approximated the nanogram range and reached lower detection limits compared with other conmon methods. The results were applied to detection in diluted fish brain tissue and a living fish brain cell. Diagnosis can also be applied in body fluid assay and in any other field requiring mammalian assay in real time.

\section{References}

1. Khandelwal, P; Beyer. C. E.; Lin. Q.: McGonigle. P.; Schechter. L. E.: Bach L. A. C. J. Newosci. Heth. 2004. 133. 181.

2. Penugonda. S.: Wul. W: Mare. S.: Ercal. N. J. Chronatogr: $B$ 2004. 807.251

3. Ornung. G: Shupliakoy. O.: Linda. H.: Ottersen. O. P.: StormMathisen. J:- Ulfhake. B: Cullheim. S. J. Comp. Keurol 1996. 365.413.

4. Awawdeh, M. A. Legako. J. A.: Harmon, H. J. Sensor Acthat. Bchent 2003. 91.227.

5. Lee. M. B.: Storer. M. K.: Blunt. J. W.: Lever. M. Clm. Chim. Acta 2006. 365.264.

6. Storer, M. K.: Lever. M. Anal. Chim. Acta 2006, 558. 319.

7. Naval. M. V.: Serranillos. M. P. G.; Carretero. M. E.: Arce. C. D. . Chromatogr: A. 2006, 1121.242.

8. Kang. X.: Xiao. J.: Huang. X.: Gu. Z. Ch. Chm. Acta 20k6. 366. 352 .

9. Veledo. M. T.: Frutos. M.: Diez-Masa. I. C. J. Chronatogr: A 2005. 1079,335 .

10. Lu. M. J. Chiu, I. C.: Chang. P. L; Ho. H. T.: Chang, H. I. Anat Chim Acta 2005. 538,143

11. Zagrobelny. J.: Chave 4. C.: Constanzer. M.: Matus cewshi. B. K. J. Pharnacetl. Bionted 1995. 13.1215.

12. Ly. S. Y.: Son1g. S. S.: Kim. S. K.: Jut1g. Y. S.: Lee. C. H. Food Chem. 2006, 95, 337.

13. Ly, S. Y; Kim. S. K.: Kim. 1. H.: Jung. Y. S.; Lee, S. M. J. Appl. Electrochem. 2005, 35, 567. 
14. Ly. S. Y.: Chae. J. I.: Jung. Y. S.: Jung. W. W.: Lee. H. J.: Lee. S. H. Nohnthg 2004. 18.201.

15. Wang. J.: Hocevar. S. B.: Ogorevc. B. Electrochent Commun. 2004. 6. 176.

16. Katz, E. Willner. I. Chem. Phys. 2004. 5. 1084.

17. Li J: Cassell A. M: Dai. H. Surf. Inferface Anal 1999. 28,8

18. Chunva, L.: Gloqing. Z.: Qingdan. Y: Jianjie, L. Bull. Korean Chem. Soc. 2006. 27. 1854.

19. Chunya. L. Bull Korean Chem Soc. 2006. 27. 991.

20. Junjie. F: Kangbing. W: Lanhua. Y: Junan. L. Bull. Korean Chem. Soc. 2005. 26. 1403.

21. Radi, A. Talamta 2005, 65,271.

22. Luo, I. W. Zhang. M.: Pang. D. W. Sensors and Actuators $B$ 2005. 106.358.

23. Kerman. K.: Morita. Y: Takamura. Y: Ozsoz. M.: Tamiya. E. Electroonal. 2004. 16. 1667.

24. Hazani, M: Hennrich, F.: Kappes, M.: Naaman, R: Peled. D.: Sidorot. V.: Shvarts. D. Chem. Plys. Lett. 2004, 391, 389.
25. Guo. M.: Chen. J.; Liu, D; Nie, L.: Yao, S. Bioelectrochemistry 2004. 62. 29.

26. Marrazza. G.: Tombelli. S.: Mascini. M.: Manzoni. A. Chin. Chim. deta 2001.307 .241$.

27. Jelen. F.; Erdem. A. E; Paleck, E. Bioelectrochemistry 2002. 55. 165 .

28. Zhen. C. H: Sun, S. G. Fan. C. J: Chen, S. P.: Mao. B. W: Fan. Y. T. Electrochin. Acta 2004. 19.1249.

29. Yeo. I. H.: Tohnsont. D. C. J. Electroanal. Chent 2001. 495.110

30. Barlow: S. M.: Kitching. K. J.: Haq. S.: Richardson. N. V. Sinf. Sci. $1998,+01,322$.

31. Seal, S.; Kuiry, S. C.; Heinmen, B. Thin Solid Films 2003, 423. 243.

32. Bnd. A. M.: Mahon. P. I.: Schiewe. J.: Beckett. V. V. Anal. Chint Acta 1997. 345.67.

33. Karadeniz. H.: Gulmez. B.: Sahinci. F.: Erdem. A.: Kaya. G. I.: Unver. N.; Kiveak, B.: Ozsoz, M. J. Phamacent. Biomed. 2003. 33.295 . 